\title{
Developing social capital: An insider look at the language learning and integration experiences of new Canadians
}

\author{
Marilyn Steinbach (Sherbrooke University)
}

\begin{abstract}
:
This article confirms the difficulties of economic and social integration for immigrants, offering qualitative data to add to the existing body of quantitative research. New Canadians need official government assistance to compensate for their lack of social capital, and educational policies and practices must also take into account the need for newcomers to develop social capital. Data from semistructured ethnographic interviews with eight adult education students in three ESL classes in Montreal indicate that these newcomers are using ethnic group contacts to negotiate access to settlement services in schools and communities. Newcomers who face social exclusion and are unable to meet their needs through official channels could benefit from government programs that create bridging social capital between immigrants and Canadian-born citizens. Education, both for new immigrants and the Canadian-born, has an important role to play in the process of making Canadian education systems and society at large more inclusive of newcomers.

Résumé

Cet article confirme les difficultés rencontrées par les immigrants dans leur intégration économique et sociale. Il ajoute des données qualitatives à l'ensemble des recherches quantitatives. Les nouveaux Canadiens ont besoin de l'assistance officielle du gouvernement pour compenser leur manque de capital social, et les politiques d'éducation aussi que les pratiques doivent aussi prendre en considération le besoin de développement du capital social des nouveaux venus. Des données obtenues au cours des entrevues ethnographiques semi-structurées de huit adultes suivant trois cours d'anglais langue seconde (ESL) à Montréal indiquent que ces nouveaux venus doivent se servir des contacts dans leurs groupes ethniques pour négocier l'accès aux services d'adaptation dans les écoles ou dans les communautés. Les nouveaux venus qui sont menacés par l'exclusion sociale et qui ne sont pas capables de satisfaire leurs besoins par les voies officielles, peuvent bénéficier des programmes du gouvernement pour assortir le capital social entre immigrés et citoyens nés au Canada. L'éducation, pour les immigrants et pour les ressortissants canadiens, joue un rôle très important dans le processus pour rendre les systèmes d'éducation et la société en général plus ouverts aux immigrants.
\end{abstract}

\section{Introduction}

This article demonstrates the necessity of official government economic and education policies and programs to compensate for new Canadians' lack of social 
capital in their new host society, reinforcing the needs expressed in existing literature (Omidvar \& Richmond, 2005; Sloane-Seale, 2005). Social capital refers to networks of resources based on relationships or social groups (Bourdieu, 1986; $\mathrm{Li}, 2004)$, as distinct from human capital, referring to resources a person has attained personally, such as education, languages, and job training (TomaskovicDevey et al., 2005). I draw from theories of social and human capital (Hébert et al, 2004; Portes, 2000; Putnam, 2000) in my analysis of the experiences of first generation Canadians, emphasizing a connection between the well-established problems of economic integration (Biles \& Burstein, 2003) and problems of social exclusion and social integration (Omidvar \& Richmond, 2005). Translating human capital into a tangible resource enabling economic integration requires government support in a new environment where social capital cannot work in the same way as it did in the country of origin. Also, in adult education contexts, the social capital that adult immigrants used in their countries of origin requires adjustment in order to function for academic and social success in a new host society. Education, both for new Canadians and for the Canadian-born population who make up the host society, has an essential role to play in the process of integrating immigrants.

In this article, I explore the ways in which eight adult immigrants from Eastern Europe, Asia, and Africa experienced the process of building social capital in the context of their host society in Montreal, Canada. While there is a significant body of literature describing the problems of economic integration of new Canadians, my research indicates a close link between economic and social integration, and focuses on the role of language learning and adult education in the process of social integration. Recent research on immigrant settlement in Israel (Remennick, 2004) identifies language acquisition as a key factor of social exclusion which is closely linked to economic participation. In New Zealand, Nash et al. (2006) identify several factors of social exclusion for newcomers, such as isolation, post-traumatic stress disorder, grief and loss, cultural and language issues, and family tensions. Omidvar \& Richmond (2005) develop the notion of social inclusion as a framework for social policy for immigrant integration, emphasizing the links between social and economic integration. The process of social integration can be perhaps better understood as inclusion, with a focus on the willingness of the host society to include the newcomers (Allen, 2006). In this paper I use the term integration to include both economic and social inclusion into the host society.

Although eight research participants are not representative of all newcomers, the depth of descriptions and underlying explanations behind what ultimately become statistics on economic integration are analyzed in detail. The data from these participants can be considered as generally representative in the sense that they describe stories and life experiences similar to those of their relatives, friends, and colleagues. These eight case studies indicate that the provincial and federal government settlement programs are not necessarily as effective as they could be. Data from the interviews indicates frustration and disappointment with official programs that do not succeed in helping newcomers 
to integrate socially and economically. Rather, new Canadians are using ethnic group contacts which act as horizontal social capital, or bonding social capital (Kunz, 2003), to negotiate access to services and opportunities necessary for settlement and integration. Within the context of their adult education classrooms and in their communities, these participants described their processes of developing social capital in their host society.

\section{Integration into Canadian society}

Although Canadian settlement programs are not always effective from the perspective of immigrants, these programs are becoming increasingly necessary due to the nation's rapidly expanding immigrant population (Statistics Canada, 2006). The Canadian economy depends on the participation of new immigrants in the workforce (Jedwab, 2004). Despite these demographic and economic trends, newcomers are not always benefiting from the educational and professional opportunities allegedly available to them in Canada. Recent immigrants are more likely to be unemployed or underemployed than Canadian-born citizens (Biles \& Burstein, 2003; Frenette \& Morissette, 2003; Picot \& Hou, 2003; Schellenberg \& Hou, 2005). 2001 census data shows that the unemployment rate of recent immigrants (12.1\%) was still nearly twice that of the Canadian-born population (6.4\%) (Statistics Canada, 2003a). Even after 10 years in the country, immigrants, including those with university degrees, earned substantially less than the Canadian-born (Statistics Canada, 2003b).

Increasingly from the early 1980s to the mid-1990s there was evidence that recent arrivals were experiencing lower rates of employment, that entry earnings were declining for certain immigrants and that the rates of low income were rising sharply for others. At the same time, it could be argued, the human capital of immigrants was increasing. Census data since 1981 bears out these patterns...There appears to be something unique about the current Canadian labor market which we have not been able to measure, which impedes immigrant access to jobs or opportunities consistent with their skills and experience. (Ruddick, 2003, p. 16)

Aside from economic concerns, there are other factors involved in settling in a new country. The Longitudinal Survey of Immigrants to Canada (LSIC) (Statistics Canada, 2003c) is a long-term study began in 2001 by Statistics Canada and Citizenship and Immigration Canada (CIC). In order to examine how immigrants adapt to and integrate into Canadian society, about 12,000 adult immigrants who came to Canada between October 2000 and September 2001 were interviewed roughly six months after they arrived. The first phase of this survey provided statistics on housing, healthcare, training, and jobs (Statistics Canada, 2003c). For example, 85\% of those surveyed reported difficulties in finding housing, and those who received assistance obtained it from friends (63\%) and from family (22\%)(CIC, 2004). This data indicates that new Canadians are 
being helped primarily by their friends and relatives, and not by official government programs. Data from my case studies concur with these statistics.

In a study of 525 Canadian refugees, Lamba (2003) states that human capital variables predict only a minuscule variance in their quality of employment, and that former education and employment have little if any impact on the jobs they attain, primarily because of systemic barriers such as discrimination. SloaneSeale (2005) concurs that human capital from immigrants is not being maximized due to three types of barriers to the Canadian labor market: dispositional, situational, and institutional, and states that institutional responses have been unsuccessful because they try to increase opportunities without removing barriers. Sloane-Seale (2005) cites cultural and systemic issues such as racism, sexism, politics, and the context and culture of the situation as the major hindrances to integration. This literature on human capital reinforces the important link between economic and social integration of newcomers to Canada. Alongside the human capital that new Canadians possess, what becomes much more crucial in the context of the new host society is their social capital which allows their human capital to benefit them realistically. Social capital is closely linked with social integration, which has been theorized in terms of civic participation, social cohesion, and social capital. I find the sociological concepts of social and human capital helpful in theorizing the gap between the human capital of new Canadians and their economic and social integration.

\section{Theories of human and social capital}

Marx understood capital as the capacity to mobilize and produce economic, political, social, and cultural resources (Hébert et al, 2004). Bourdieu (1986) used the terms economic, cultural, and social capital to emphasize the instrumental aspect of how these resources can be traded (Portes, 2000). Human capital, thus, refers to the resources a person has attained, such as education, languages, and job training, by making "investments in their own set of productive skills" (Tomaskovic-Devey et al., 2005, p. 60). In contrast to the specific resources that comprise human capital, Bourdieu defines social capital as "resources which are linked to possession of a durable network of more or less institutionalized relationships of mutual acquaintance and recognition” (Bourdieu, 1986, p. 248). $\mathrm{Li}$ (2004) summarized social capital as a resource that individuals can use as a result of their connection to a social group, and pointed out the investment and maintenance necessary in order to gain benefits from these connections. Social capital has been divided into bonding capital, which refers to relations among family and ethnic group, and bridging capital, referring to relations between ethnic groups, or between immigrants and Canadian-born (Kunz, 2003). Zacharakis (2005) states that although bonding capital gives a community an identity and purpose, it could become too narrow and limit members' access to important information and resources if there were no bridging ties across the social divides of religion, ethnicity, and socioeconomic status.

$\mathrm{Li} \mathrm{(2003)}$ argues that the human capital model ignores the influences of structured inequality that are already deeply entrenched. He compares earnings of 
different groups of immigrants, finding that white immigrant men have the least disadvantage compared to their Canadian born counterparts (\$3,600 to 5,700 less salary per year), and visible minority immigrant women have the greatest disadvantage ( $\$ 6,000$ to 8,000 less per year). He argues that aside from their human capital, the performance of immigrants in the labor market depends on "how prepared Canadian society is to reward them in the same manner as nativeborn Canadians, irrespective of superficial differences in gender, race, and nativity” (Li, 2003, p. 112).

Taking macro-level structural inequalities into account, I draw on the notions of human and social capital to theorize my research participants' experiences of social and economic integration. While Statistics Canada provides valuable quantitative data to observe broad trends, data from my interviews offers a qualitative look at some of the explanations behind these statistics. The following case studies demonstrate that newcomers are using informal, unofficial channels because the official ones are not effective. These case studies reveal some of the reasons why government settlement programs were not effective in translating the human capital of the eight research participants, who, although not representative of all newcomers, offer rich, descriptive data to help us understand the statistics.

\section{Case studies in Montreal}

In 2002-2003, I observed English as a second language classes in three adult education schools in Montreal, Quebec, and completed semi-structured in-depth interviews with eight volunteer research participants to obtain an emic (insider) perspective on their integration experiences. I used random purposeful sampling (Patton, 1990) to select the five female and three male research participants; all adults who had immigrated to Montreal within the previous five years of the interviews. They came from Algeria, Belarus, Ethiopia, Kazakhstan, Kurdistan, Pakistan, Sri Lanka and Vietnam. Theoretical analysis of the interview data took into account both the micro-level, personal experiences of the participants and the macro-level, political, economic, systemic factors that influenced their perceptions of their experiences. I identified themes and categories from the interview data (Bogden \& Biklen, 1992), used a content analysis process to confirm and refute categories (Sloane-Seale, 2005), and triangulated my data with the participants after the interviews.

One of the most striking patterns that emerged from all of the interview data was the way the participants managed to access resources to meet their basic needs without any help from settlement services provided by the government. Without relatives here in Canada, they eventually accomplished the difficult tasks of finding housing, daycare, language classes and/or public schools through the help of ethnic group contacts. Participants made friends with people from their own linguistic and geographical backgrounds, thus using bonding social capital within their own ethnic groups. They expressed frustration about their lack of social capital, and disappointment with the lack of help from official government programs and centers in meeting both initial and more long-term settlement needs. 
In this paper I provide descriptions of the perspectives of seven of these immigrants on the facts of their settlement experiences that demonstrate how official government services and programs have failed to assist them in creating social capital which works to translate their human capital into tangible economic and social outcomes.

Two research participants came to Canada while they were still secondary school students. The other six participants expressed difficulties in finding information on government programs to assist in getting settled in their new host society. "...only friend says to friend, like that...they have no contacts, they have not information, it's difficult” (Anya, Interview \#3, 16/08/02). Quotes like this were ubiquitous in the interview data, and representative of the experiences of all the participants with regard to the organization of settlement services and the availability of information and programs. Most participants were surprised at the lack of organization and help available for the first few weeks of settling in. Anya from Belarus, for example, recounts this encounter with an immigration official on her second day in Canada.

She gave the address of the, I don't remember the name of this organization, but she told they could help you with apartment, with job, with, if you need, for example, if you have no money, with food, with furniture, OK, the next day we went that place, but a woman who was there, and she told, "hello, take a seat, what do you want?" And we told "maybe you can help with work?" "No." "Maybe you can help with furniture?" "No." "What are you doing here?" we asked. "Uh, you can pay us money and be member of our club, and we can uh, register you for the French classes [Carrefour d'intégration], and that's it. That's all. Thank you, goodbye.” (Anya, Interview \#3, 16/08/02)

Although an immigration officer had referred them to this organization, Anya and her husband perceived that none of the services they had been promised were actually available at this organization. They did not need to pay anyone to help them register for Carrefour d'intégration classes, as they were already on waiting lists. Later, through Russian friends, she discovered another non-government organization which she claims really does help immigrants. Anya believes that newcomers like herself need to have personal connections to find out about these helpful organizations, because no one at the immigration offices told her about them.

Shira, from Kurdistan, expressed exasperation with people who work in immigration offices in Montreal.

Yeah, very disorganized! The people who work in immigration ...offices, they really doesn't care, you know, because my case is there. I know it's not just me, but I have been in this country for many year without any answer. (Shira, Interview \#2, 12/08/02)

Shira and her husband found their apartment through a Kurdish friend. Years later she also found out about the community center where she was studying English 
through another Kurdish acquaintance. During her first year in Canada, her overwhelming difficulties finding daycare kept her from being able to take French courses offered by the provincial government. It took her over a year to find out about a community center where she could obtain daycare.

I cried there, I said please, I need some course...I couldn't get daycare. I begged them for one day, or 2 days...every 2,3 months I went back, and I asked for courses, but they never have a place available for me. No daycare I could find for myself, and I didn't know anybody here, and I had not good income to hire somebody to watch two kids. (Shira, Interview \#3, 04/09/02)

Shira experienced problems enrolling her children in elementary public school in Montreal. After presenting their accepted refugee papers and registering their children at the local French language primary school, she was notified ten days later by the school that she needed to pay $\$ 9,000$ for her two children to attend this public school. Shira visited several provincial government offices in desperation, always unable to get any explanation for this problem. Eventually, an acquaintance informed her that she need only ask a bank director for a note stating that her children were under 16 and had the legal right to public education. Once she obtained that note her children were allowed to attend the public school. She has filed reports and made complaints, but has never received any more information on this matter. The barriers Shira encountered in enrolling her children in school are a typical example of problems which are extremely hard to cope with for immigrants who do not have any social network or familiarity with administrative norms in public institutions in Canada. In this case her lack of social capital had direct consequences on the social integration of her family.

Gulruk, from Kazakhstan, found an apartment for the first month from a Russian landlord whom she contacted from information in a Russian newspaper in Montreal. Establishing a social network among Russian immigrants was the way that Gulruk managed to meet all of her initial settlement needs. An acquaintance helped her with the logistics of banking and setting up a telephone. A Russian friend directed her to the school board to find a school for her daughter. Another Russian contact told her about the community center where she was taking English courses. She found this multiethnic community center's environment very supportive.

...people were in the same situation as me, there are a lot of refugees there. We could complain to each other in Russian! People like me understand the suffering.” (Gulruk, Interview \#3, 21/08/02)

Gulruk provides some insight into how language barriers blocked her social capital from working outside her linguistic community.

It's difficult to make friends in a new country, because it's a different language and a different mentality. I'm afraid to speak, I want to communicate, but I'm afraid of making mistakes, I can't express myself 
completely. But in Russian we talk jokes, funny things, this is impossible in English! (Gulruk, Interview \#4, 13/09/02)

Gulruk's discomfort in communicating in English exemplifies Bourdieu's (1986) notion of linguistic capital. She felt the symbolic domination of the legitimate language which convinces us that its tacit rules are universal and objective (Bourdieu, 1991).

Van Do, from Vietnam, criticized the Canadian immigration system, particularly in terms of settlement services. He was greatly disappointed in the discrepancy between the welcoming image portrayed by the Canadian immigration advertisements overseas and the realities of life when he actually arrived.

You know, before we came here...they need the, the people with the certain quality. But when we come here, we uh, we have a feeling in Canada there is something is not in the good voice, you know? Because when we come here, we just see the, the publicity, advertisement, you come here and we build together our country. It's ah, a good uh, image, you know? And then when we go, when we began to live, the strings become disappear, you know? (Van Do, Interview \#2, 11/08/02)

He continued:

...the most intellectual from the other country...but I don't know, if Canada uh, need the newcomer who have the certain level of technology or not, but, the most of them have to work uh, manually. This is a kind of human wasting. (Van Do, Interview \#2, 11/08/02)

Although Van Do is a chemical engineer and his wife is a pharmacist, their university degrees and professional experience are not recognized in Canada. He has been working at manual labor jobs to support his family. He and his wife felt that they didn't receive the support they had been promised by the Canadian government. Although they were selected to immigrate based on their education and work experience, it has been too difficult to acquire equivalencies for their degrees. They never had the time or opportunity to retrain here because of the financial responsibilities of raising their children. As he and his wife felt extreme pressure to begin working as soon as they arrived, jobs were their first priority after the basic necessities such as finding an apartment. Van Do had a poetic way of explaining his lack of social capital in Canada:

But when we come here, we had no information, just, we became handicapped, you know? Uh, we don't have the relation, we couldn't speak the English, neither the French well, then we became a handicap, for example, the blind, and, you know? We fall down in the strange atmosphere. (Van Do, Interview \#2, 11/08/02)

Van Do's metaphor of a handicap is poignant in its direct allusion to his experience of a lack of ability to function socially and economically as he had in his country of origin. His metaphors clearly illustrate his perspective of a lack of 
effective social capital in his new environment, which he experiences as a "strange atmosphere". He described his experience of systemic barriers to his integration process as a feeling that "something is not in the good voice". Van Do's discomfort is broader than Gulruk's communication obstacles, expanding from personal issues to wider structural barriers. Aside from the initial settlement challenges of finding housing, daycare, and education without social capital that works in a new linguistic and cultural context, this lack of effective social capital also caused Van Do's family to experience social exclusion.

A similar social exclusion was described by the three participants who were studying full time in an adult education center where they had difficulties entering into the discourse style prevalent in this educational context. They all spoke of being too shy to express themselves in the classroom the way Canadianborn students could. In my analysis of this recurrent theme from the interview data, I understood their use of the term shyness and their descriptions of how they overcame shyness to incorporate notions of courage, confidence, boldness, openness, and freedom to speak out, sometimes to the point of breaking norms of respect. Their descriptions of shyness in the interview data are inextricably linked with power relations.

For example, Nilufar noticed the frank, blunt discourse style that is typical of North Americans, explaining that Sri Lankans did not have a similar discourse style, and lacked the liberty to speak openly. However, she observed that it was natural for Canadians, even young Canadians who are the children of immigrant parents, to speak frankly. She noted the changing discourse patterns of her younger classmate Zishan from Pakistan. I also noted that although Zishan expressed disgust at the attitudes and behaviors of his Canadian-born colleagues, he began to adapt similar attitudes and work ethic as he integrated into the classroom culture of his adult education school.

At first Zishan commented on the impudence of Canadian adolescents, feeling somewhat shocked at their behavior which seemed extremely disrespectful to him.

Why don't parents say anything when teenagers here drink beer and smoke? Why their parents let them do this? Here students smoke in front of teacher? In my country we stand up and be quiet when teachers comes in. (Zishan, Interview \#4, 26/09/02)

Zishan learned to overcome his shyness here in Canada, and was forced to adapt a different discourse style. Yet, he continued to experience social exclusion due to what he referred to as the private nature of Canadians compared to the social norms in Pakistan.

They don't talk too much, they just go for Québécois...They're busy their own self...and they feel tired because, like, they work hard too. You know, they don't have enough time to talk. They're busy, tired, they just need time to relax. I think they feel better alone sometimes. (Zishan, Interview \#4, 26/09/02) 
He understood his lack of social capital with Canadian youth as partially due to the multicultural demographics of Montreal, compared to the homogeneity of his country of origin.

...over there [Pakistan] you could meet some people, and they, you know, you could make them friend right away. Because the kind of people, they is really friendly. They talk to each other, and you become a friend. And here it take time, because there is like difference between cultures... there is all the same kind of people, that's why the people know each other, they know how to...people know you, and, because they know you, like, you have a good family and this and that. (Zishan, Interview \#4, 26/09/02).

Roshan, from Ethiopia, also experienced social exclusion, often reiterating how she missed the open social relations in her country as compared to the Canadian norms.

...in my country, you know each other. Even, or imagine if I live in the same building, I know everybody from the upstairs or downstairs, like, I don't even know who is living next to our apartment, I don’t even know them, it's uh, weird, that thing, for me was. (Roshan, Interview \#2, 25/09/02)

She also spoke at length of overcoming shyness in order to succeed in her Canadian academic environment. Although young adults like Roshan and Zishan adapted new discourse patterns in order to function in their host society, they still did not have any Canadian friends after two years of attending a school where the majority of students were Canadian-born. It was even more difficult for the other six participants who arrived after the age of twenty-five to integrate socially into Canadian society. With the exception of Shira, none of these participants had friends outside of their ethnic groups, although they had been in Canada for an average of 2.8 years. Not one of these eight participants had ever been inside of what they referred to as a real Canadian (Canadian-born person's) home before coming to my apartment for interviews.

\section{Building bridging social capital}

Why is it so difficult for newcomers to establish friendships with Canadian-born people? The social exclusion these 8 participants experienced was accepted as something inevitable that could not be questioned, whereas exclusion from the labor market was less acceptable. Their sense of frustration about recognition of foreign education and work experience surfaced strongly in the interview data. They expected official government services to be more effective, yet all of the participants met their basic settlement needs through contacts within their own ethnic groups. Although they made efforts to adopt Canadian-style discourse patterns to achieve academic and social success, they remained socially excluded in their adult education contexts. The participants tried to understand their frustrations in terms of differences in values, social practices, or discourse norms 
between their countries of origin and Quebec. Although Van Do hinted at a broader political context of injustice, the other seven participants did not relate their experiences to larger systemic inequalities embedded in attitudes, practices, and social norms.

One of the major factors excluding new Canadians from jobs, educational institutions, and social activities emerging from my inquiry is participants' lack of social capital that works in the context of their new host society. An examination of the experiences of Montreal participants in other research (Lenoir-Achdjian et al, in press) reveals both surface level and deeper level hindrances to their access to services, education, and the job market. As all public resources are limited, difficulties in obtaining daycare and jobs are not an unusual occurrence for anyone in Montreal. However, it is exactly in this context where the difference between newcomers and native-born Canadians are enormous in terms of their abilities to mobilize social capital to access these opportunities. As Van Do so candidly stated, new Canadians are handicapped in terms of knowing how to access necessary services.

Aside from the obvious obstacles such as a shortage of daycare spots or jobs available, and the complexities of recognizing foreign education and work experience, covert hindrances may be even more significant. Labor market barriers for new Canadians are systemic and require structural, systems-based solutions (McIsaac, 2003). In many cases, conscious or subconscious levels of discrimination come into play in this decision making process. "As Reitz (2005) and Jackson (2001) note, racial attitudes may underlie requirements for Canadian work experience, and judgments that a foreign credential is a lower standard than Canadian qualifications may reflect discriminatory bias” (Sadiq, 2005, p. 63). Because of the underlying assimilationist ideology historically present in Canadian society (Steinbach, 2004), the structural and political elements of public discourse (Brah, 1996), and the macro-level discourses and underlying political structures that position people as others from a normative point of view (Sassen, 1998), mainstream Canadians function within a set of social norms and discourses that automatically create barriers for newcomers. Perceptions of what is normal among the citizens of a community create an underlying structure of norms that is difficult to circumvent for those who do not share the same perceptions. Thus, norms are formed by groups of people who share similar experiences and values, and will clearly differ between newcomers and Canadian-born people. These cultural norms also hold power which plays a significant role in educational institutions, as critical pedagogy scholars describe these cultural norms as "inscribed in and through culture, leading to practices of domination and exploitation that have become naturalized in everyday social life" (Trueba \& McLaren, 2000, p. 54).

By arguing that schools reproduce the social value of linguistic competence and its' ability to function as linguistic capital, Bourdieu (1991) enforces the notion that educational institutions have an important role to play in changing the patterns of social reproduction that maintain the exclusionary nature of Canadian society so difficult for new Canadians to penetrate. When theorizing 
the role of education in the creation of bridging social capital, concerns revolve around how official government programs can assist newcomers in learning, changing, or growing into the position of being able to make links. More attention could be given to the other end of the bridge, that is, the Canadian-born population with whom these links are supposed to be created. There has been increasing acknowledgement in recent immigration literature (Azmier, 2005; Belkhodja, 2005; Winnemore \& Biles, 2006) of the emphasis on the other side of the "twoway street of integration" in which "both immigrants and the host society make an effort, both are mutually involved” (Frith, 2003, p. 36). McIsaac points out the need to "build the capacity of the various stakeholders at the local level, including educational institutions, regulators, employers, non-governmental organizations that deliver settlement services, and particularly the municipalities themselves" (McIsaac, 2003, p. 6). In order to change assimilationist and discriminatory ideas and behaviors, they must be acknowledged. Education, both in public schools and throughout the general population, is required in order to allow citizens to recognize their tacit assumptions and the ways in which these beliefs affect their social practices. Discourse patterns which foster an ongoing mentality of eurocentric imperialism could be eroded through education that promotes awareness of underlying beliefs, attitudes, and values along with their ensuing practices. Changing deeply embedded structures will not be easy, but considering how far we have come, there is reason for optimism that Canadian society is well on its way to becoming more welcoming to new Canadians.

\section{References}

Allen, D. (2006). Who's in and who's out? Language and the integration of new-immigrant youth in Québec. The International Journal of Inclusive Education,10, (2-3), 251263.

Azmier, J. (2005). Western Canada's unique immigration picture. Canadian Issues, Spring 2005, 116-118.

Belkhodja, C. (2005). Immigration and the challenge of regionalization: Francophone immigration in New Brunswick. Canadian Issues, Spring 2005, 112-115.

Biles, J. \& Burstein, M. (2003). Immigration: Economics and more. Canadian Issues, April 2003, 13-15.

Bogden, R. \& Biklen, S. (1992). Qualitative research for education. Boston: Allyn and Bacon.

Bourdieu, P. (1986). The forms of capital. In J. Richardson (Ed.), Handbook of theory and research for the sociology of education (pp. 241-258). Westport, CT: Greenwood Press.

Bourdieu, P. (1991). Language and symbolic power. Oxford: Polity Press.

Brah, A. (1996)._Cartographies of diaspora: Contesting identities. New York: Routledge. 
Citizenship and Immigration Canada (2004). The Monitor: Highlights for the third quarter, 2003. Highlights is an abbreviated version of the THE MONITOR, from www.cic.gc.ca.

Frenette, M. \& Morissette, R. (2003). Will they ever converge? Earnings of immigrant and Canadian-born workers over the last two decades. Statistics Canada, Analytical Studies Research Paper Series No. 215, Catalogue No. 11F0019M1E, Ottawa.

Frith, R. (2003). Integration. Canadian Issues, April 2003, 35-36.

Hébert, Y., Sun X., \& Kowch, E. (2004). Focusing on children and youth: The role of social capital in educational outcomes in the context of immigration and diversity. Journal of International Migration and Integration 5(1), 229-249.

Jedwab, J. (2004). Intersecting identities and dissecting social capital in Canada. Canadian Diversity 3(1), 17-19.

Kunz, J. (2003). Social capital: A key dimension of immigrant integration. Canadian Issues, April 2003, 33-34.

Lamba, N. (2003). The employment experiences of Canadian refugees: Measuring the impact of human and social capital on quality of employment. Canadian Review of Sociology and Anthropology,40 (1), 43-64.

Lenoir-Achdjian, A., I. Drainville, D. Helly, S. Arcand, M. Vatz-Laaroussi et A. Mahfoudh. (in press). L'insertion professionnelle d'immigrants originaires du Maghreb : défis et obstacles pour l'intervention. Journal of International Migration and Integration, Special edition.

Li, P. (2003). Destination Canada: Immigration debates and issues. Don Mills, Ontario: Oxford University Press.

Li, P. (2004). Social capital and economic outcomes for immigrants and ethnic minorities. Journal of International Migration and Integration 5(2), 171-190.

McIsaac, E. (2003). Nation building through cities: A new deal for immigrant settlement in Canada. Ottawa: The Caledon Institute of Social Policy.

Nash, M., Wong, J., \& Trlin, A. (2006). Civic and social integration: A new field of social work practice with immigrants, refugees and asylum seekers. International Social Work, 49 (3), 345-363.

Omidvar, R. \& T. Richmond (2005). Immigrant settlement and social inclusion in Canada. In Richmond \& Saloojee (Eds.). Social Inclusion: Canadian Perspectives (pp. 155179). Halifax: Fernwood Publishing.

Patton, M. (1990). Qualitative evaluation and research methods. Newbury Park, CA: Sage Publications.

Portes, A. (2000). The two meanings of social capital. Sociological Forum, 15(1), 1-12.

Picot, G. \& Hou, F. (2003). The rise in low-income among immigrants in Canada. Statistics Canada, Analytical Studies Research Paper Series No. 198, Catalogue No. 11F0019, Ottawa.

Putnam, R. (2000). Bowling alone: The collapse and revival of American community. New York: Simon and Schuster.

Remennick, L. (2004). Language acquisition, ethnicity and social integration among former Soviet immigrants of the 1990s in Israel. Ethnic and Racial Studies, 27 (3), 431-454.

Ruddick, E. (2003). Immigrant economic performance: A new paradigm in a changing labour market. Canadian Issues, April 2003, 16-17.

Sadiq, K. (2005). Race, ethnicity and immigration in the workplace. Canadian Issues, Spring 2005, 61-66.

Sassen, S. (1998). Globalization and its discontents: Essays on the new mobility people and money. New York: The New Press.

Schellenberg, G. \& Hou, F. (2005). The Economic well-being of recent immigrants to Canada. Canadian Issues, Spring 2005, 49-52. 
Sloane-Seale, A. (2005). New immigrants' barriers to participation in society and the economy. Canadian and International Education Journal,34 (2), 55-71.

Statistics Canada, 2006. Canada’s population. The Daily, September 27, 2006. Retrieved June 5, 2007, from http://www.statcan.ca

Statistics Canada, 2003a. Census of population: Labour force activity, occupation, industry, class of worker, place of work, mode of transportation, language of work

and unpaid work. The Daily, February 11, 2003. Retrieved May 21, 2003, from http://www.statcan.ca

Statistics Canada, 2003b. Census of population: Earnings, levels of schooling, field of study and school attendance. The Daily, March 11, 2003. Retrieved May 24, 2003, from http://www.statcan.ca

Statistics Canada, 2003c. Longitudinal survey of immigrants to Canada. The Daily, September 4, 2003. Retrieved September 21, 2005, from http://www.statcan.ca/Daily/English/030904/d030904a.htm

Steinbach, M. (2004). Equity for new Canadians: Considering cultural worldviews in adult education. Doctoral thesis, Ontario Institute for Studies in Education, University of Toronto.

Tomaskovic-Devey, D., Thomas, M. \& Johnson, K. (2005). Race and the accumulation of human capital across the career: A theoretical model and fixed-effects application. American Journal of Sociology, 111(1), 58-89.

Trueba, H. \& McLaren, P. (2000). Critical ethnography for the study of immigrants. In Trueba \& McLaren (Eds.), Immigrant voices: In search of educational equity. (pp.37-73). New York: Rowman \& Littlefield Publishers Inc.

Winnemore, L. \& Biles, J. (2006). Canada's two-way street integration model: not without its stains, strains and growing pains. Canadian Diversity, 5_(1), 23-30.

Zacharakis, F. (2005). Riverside: A case study. Adult Education Quarterly, 55, 288-307.

Dr. Marilyn Steinbach is a professor in the faculty of education at Sherbrooke University, and teaches courses in second language pedagogy and intercultural education. Her interests are in socio-cultural factors related to language learning and teaching, multicultural education, intercultural relations, and the integration of new Canadians. Her current research projects explore the socio-cultural integration of immigrant secondary students, and the relations between immigrant families, schools, and communities. 